\title{
Kontestacja à rebours. O pisarstwie i nie-pisarstwie Karla Michala
}

\begin{abstract}
Czernikow Olga, Kontestacja à rebours. O pisarstwie i nie-pisarstwie Karla Michala (Contestation à rebours. On Writing and Non-Writing of Karel Michal). „Poznańskie Studia Slawistyczne" 6. Poznań 2014. Publishing House Science and Innovate, pp. 63-74. ISBN 978-83-63795-51-1. ISSN 2084-3011.

The problem of transfer from the official to the unofficial culture is one of the most significant phenomena in the post-war Czech literature history. Resistance against the limitations on creative autonomy set by the government led to the emergence of particular contestation attitudes and to the creation of counterculture, understood as a dissident and exile culture, as well as the underground. In this landscape, Karel Michal's position is peculiar and difficult to classify; his contestation is total, as it is pointed at not only the subordination of literature to norms set by the regime, but also at the expectations put on it by the dissident community. In texts which appeared during his exile, he presents an uncompromising approach to the issue of the engagement of literature and roles assumed by a writer arbitrarily. A consequence of his radical position is the growing imperative to not write, which leads to his complete withdrawal from literary life.
\end{abstract}

Keywords: Karel Michal; exile literature; censorship; contestation; negation; identity

Josef Kroutvor w swojej znanej książce Potiže s dějinami pisze o wychodźstwie jako modelowym przykładzie tytułowych kłopotów z historią, polegających w tym wypadku na radykalnej zmianie w postrzeganiu przeszłości i teraźniejszości. Emigracja sytuuje jednostkę poza procesem dziejowym w roli obserwatora, który świadomie percypuje tenże proces (Kroutvor 1990: 125). W konsekwencji emigrant, będąc niejako na orbicie wydarzeń (a nie, jak do tej pory, w ich centrum), postrzega zarówno historię w materialnej procesualności, jak i pozycję, jaką zajmuje. Innymi słowy, dopiero będąc „na zewnątrz” historii, może w pełni zdać sobie sprawę z jej istnienia. Opozycję wewnątrz - na zewnątrz Kroutvor rozpatruje w kategoriach czasowych („było - jest” czy też „wtedy - teraz”), trzeba jednak zauważyć także analogiczne przeciwstawienie w obrębie relacji przestrzennych. 
Emigracja oznacza przecież opuszczenie jednego terytorium i osiedlenie się na drugim. Tym samym binarne przeciwieństwa współistnieją w superpozycji: „teraz i wtedy” oraz „tutaj i tam”. Nakładanie się dwóch negatywnych (bo będących poza zasięgiem podmiotu, a zatem nieobecnych w jego percepcji) planów - czasu i przestrzeni - determinuje los pisarza emigranta, którego drogę twórczą w nowej rzeczywistości wytyczają współrzędne podwójnego wyobcowania. W tej perspektywie continuum tożsamości zostaje zakwestionowane, a sama tożsamość jawi się jako coś nieoczywistego, jako nietrwała struktura, którą trzeba wciąż na nowo rekonstruować.

Dychotomia czasoprzestrzenna przekłada się też na metodologię badań, pozwala bowiem definiować i postrzegać literaturę emigracyjną nie tylko w kontekście terytorialnym (jako literaturę powstałą za granicą), ale także historycznym (jako rezultat określonych procesów). W ten sposób zjawiska w obrębie literatury emigracyjnej (czy też - w szerszym kontekście - literatury niezależnej) podlegają interpretacji zarówno w wymiarze diachronicznym, jak i synchronicznym. W pierwszym przypadku mowa o ustaleniu mechanizmów przejścia ze sfery literatury oficjalnej do nieoficjalnej, w drugim - o wyodrębnieniu modelowych postaw, reprezentowanych przez twórców, którzy takiego przejścia dokonali. Schemat transferu jest znany: kiedy nadrzędny wobec twórcy system (polityczny, społeczny czy religijny) utrudnia, ogranicza lub wręcz uniemożliwia indywidualny i nieuwarunkowany doktrynalnie przekaz, dochodzi do konfliktu na płaszczyźnie twórca - establishment, którego rezultatem jest albo kompromis, albo świadoma rezygnacja z uczestnictwa w kulturze oficjalnej. W zależności od drogi, którą pójdzie kontestator, wystąpienie (dobrowolne lub wymuszone) z głównego nurtu może oznaczać przejście do artystycznego podziemia, emigrację wewnętrzną lub do innego kraju (systemu). Według tych wyborów kształtują się odpowiednio postawy dysydenta, twórcy undergroundowego albo emigranta. W każdym z przypadków, zakładanym rezultatem schizmy, jaką staje się transfer z kultury oficjalnej do nieoficjalnej, jest odzyskanie niezawisłości twórczej wypowiedzi, możliwość publikowania (co prawda często jedynie dla niewielkiego grona wtajemniczonych, jak w przypadku wydawnictw samizdatowych) lub zapewnienia sobie innych form kontaktu z odbiorcą. Opisany mechanizm - z większymi lub mniejszymi odchyleniami - można dostrzec w losach setek pisarzy niezależnych, których biografie i bibliografie tworzą alternatywny leksykon literatury danego obszaru. Zauważyć go 
można niewątpliwie także u Karla Michala, którego twórczość jest tematem niniejszego artykułu. W przypadku autora Straszydet przedstawiony wyżej algorytm działa jednak wbrew przewidywaniom.

Kiedy Michal we wrześniu 1968 roku decyduje się opuścić Czechosłowację, jest już cenionym i chętnie czytanym autorem. Krótko po spektakularnym sukcesie debiutanckiego opowiadania Plívník dlaždiče Housky (1959) wydaje nowelę kryminalną Krok stranou (1961) i zbiór opowiadań Bubáci pro všední den (1961). W drugiej połowie lat 60. XX wieku wychodzi eksperymentalne opowiadanie Gypsová dáma oraz powieść historyczna Čest a sláva, której filmowa adaptacja Hynka Bočana przynosi pisarzowi międzynarodowy rozgłos (film otrzymuje nagrodę między innymi na festiwalu w Wenecji w 1969 roku). To jednak Straszydła na co dzień są książką, którą Michal trwale zapisał się w świadomości czytelniczej, zyskując zarazem jednomyślny aplauz krytyki. Interesujący jest fakt, że ów cykl opowiadań, bezlitośnie obnażających absurdy życia w państwie socjalistycznym, z równym powodzeniem figuruje na liście lektur ówczesnych kontestatorów, jak i w oficjalnym kanonie powojennej literatury czeskiej.

Jako autor Michal funkcjonuje więc na granicy dwóch obszarów - kultury oficjalnej i nieoficjalnej - konsekwentnie unikając jednak arbitralnego przyporządkowania do któregokolwiek z nich. Nie jest ulubieńcem władz, ale nikt go nie szykanuje. Po wielu latach pracy (przeważnie fizycznej) na najniższych stanowiskach, doczekuje się w końcu posady lektora w wydawnictwie Naše vojsko, co zapewnia mu stabilizację materialną i zawodową. Decyzja o emigracji nie zapada jako następstwo traumatycznych doświadczeń, dotykających pisarza osobiście, nie wynika z boleśnie odczuwanego ograniczenia swobód obywatelskich czy wolności słowa. Michal nie jest zmuszony do opuszczenia kraju - ani bezpośrednio przez nakaz władz, ani pośrednio przez brak możliwości twórczego realizowania się. To decyzja podyktowana silnym wewnętrznym imperatywem, radykalną niezgodą na uczestnictwo - choćby w charakterze świadka - w procesie, którego siłą napędową są absurd i relatywizacja wartości, z takim zacięciem piętnowane w jego utworach. Wkroczenie wojsk Układu Warszawskiego stało się bodźcem do podjęcia decyzji, która dojrzewała od dłuższego czasu. Należy podkreślić szczególny charakter postanowienia Karla Michala: ówczesna sytuacja życiowa pisarza nie wskazywała na to, że opuszczenie kraju mogłoby być konieczne lub w jakikolwiek sposób korzystne. Osobliwy, silnie 
uwewnętrzniony akt kontestacji Michala nadaje szczególny rys jego losom na wychodźstwie. Pobyt pisarza w Szwajcarii przebiega pod znakiem wycofania, rezygnacji i uporczywego podawania w wątpliwość własnego statusu jako twórcy. Program metodycznej negacji - o czym będzie jeszcze mowa - stanie się dla Michala fundamentem kreowania autorskiego ja. Pisarz konsekwentnie odmawia uczestnictwa w życiu publicznym, unika zaangażowania w sprawy emigrantów, ale też odrzuca przywileje przysługujące mu z racji statusu uchodźcy politycznego. Mechanizm przejścia z kultury oficjalnej do nieoficjalnej działa więc w jego przypadku w zgoła nieoczekiwany, przewrotny sposób: przyjazd do demokratycznego państwa nie tylko nie otwiera przed autorem Straszydet... nowych perspektyw twórczej realizacji, lecz także skłania go do porzucenia również dotychczasowych. Emigracji terytorialnej towarzyszy więc emigracja wewnętrzna. W ten sposób Michal staje się dysydentem w pierwotnym i uniwersalnym znaczeniu tego słowa: jest tym, kto „siedzi po przeciwnej stronie” (dissidere), protestuje przeciw arbitralnie przyjętym formom podporządkowania. Buntuje się niejako podwójnie: poprzez wychodźstwo wyraża sprzeciw wobec systemu totalitarnego, poprzez emigrację wewnętrzną - odrzuca role, jakie mu narzuca emigracyjna (i nie tylko) społeczność. W tym sensie kontestuje więc samą kontestację.

Takie stanowisko zajmuje też w pierwszym wydanym po wyjeździe utworze, krótkim eseju - czy raczej przemowie - pod tytułem Přemilí souse$d e^{1}$ (Michal 2001a). Jest to bez wątpienia jeden z najbardziej zagadkowych i trudnych w odbiorze tekstów autora Kroku stranou, zarówno ze względu na skomplikowany plan formalny, jak i zawarte w nim treści. Kolejne sensy odsłaniają się stopniowo i nie wprost, w ironicznej perspektywie nawarstwiających się zaprzeczeń. Pretekstem do przedstawienia owej osobliwej mowy jest próba podsumowania koegzystencji przybysza-cudzoziemca i jego sąsiadów. Refleksja ta daje asumpt do rozmaitych uwag (wyrażanych zazwyczaj aluzyjnie) pod adresem obu stron ( $\mathrm{tj}$. przybysza i sąsiadów, a w szerszym kontekście - Czechów i Szwajcarów), rychło przeradzających się w bezlitosną drwinę. Utwór ukazał się w 1972 roku w antologii Das

${ }^{1}$ Ze względu na temat i objętość niniejszego artykułu omówienie tego utworu musiało zostać ograniczone do przedstawienia jednej tylko linii problemowej. Szczegółowej analizie Přemilých sousedi̊ poświęciłam odrębne studium (Czernikow 2010: 381-390). 
kalte Paradies. Emigration - Intergration - Konfrontation, potem zaś został przedrukowany w emigracyjnym czasopiśmie „Zpravodaj”. Esej wywołał histeryczną reakcję czeskich emigrantów, których oburzała nie tyle czytelna w tekście kpina z ich narodu, ile cierpkie aluzje pod adresem Szwajcarów. Do redakcji napływały listy, w których czytelnicy w mniej lub bardziej agresywny sposób potępiali Michala za to, że „kala nie tylko swoje gniazdo, ale i to szwajcarskie” (Fischerová 2008: 159) oraz że z jego winy „nasze dzieci nie będą miały wstępu do szkół wyższych, a naszym przedsiębiorcom zakaże się prowadzenia działalności” (Fischerová 2008: 159).

Absurdalny charakter zarzutów dowodzi czegoś więcej niż tylko powierzchownej lektury i niemożności czy niechęci dostrzeżenia głębokich, acz nieoczywistych sensów, kryjących się w wielowarstwowej strukturze utworu. Wskazuje przede wszystkim na problem, z którym czeska literatura emigracyjna - być może też czeska literatura w ogólności ${ }^{2}$ - borykała się przez wiele lat, a który wówczas stał się szczególnie dotkliwy. Chodzi o przyjęte a priori przeświadczenie o funkcjonalnym charakterze literatury, o jej politycznej czy społecznej roli. Takie podejście narasta w okresie zagrożenia dla continuum dziedzictwa kulturowego. Na emigracji groźba zerwania ciągłości jawi się w ekstremalnej formie jako gwałtownie postępujący i nieuchronny proces, przeciwko któremu należy jak najszybciej przedsięwziąć środki zaradcze. Nawiązywanie do przeszłości (pojmowanej nie tylko w kategorii czasowej, ale i przestrzennej; nie tylko ,wtedy”, ale również „tam”) i zintensyfikowana refleksja nad wydarzeniami poprzedzającymi emigrację mają stać się antidotum na dokonujący się - lub niemal już dokonany - rozłam. Od twórcy oczekuje się ,scalania” pamięci narodowej, gotowości do nieustannego zaświadczania o tym, co było. Świadectwo pisarza zyskuje podwójną wartość - po pierwsze dla samej diaspory, stając się czynnikiem reintegrującym tożsamość kulturową, po drugie dla zagranicznej opinii publicznej jako wypełnienie faktograficznej luki. Ten stan

2 Wnikliwą analizę konfliktu pomiędzy arbitralnie przyjętym programem czeskiej literatury narodowej a indywidualną potrzebą ekspresji przedstawił Josef Jedlička w swoim eseju Okraj a střed. „V Čechách byl obsahem uměleckého vývoje vždycky spor mezi objektivní potřebou vytvořit členitou, obsáhlou a dosti reprezentativní národní kulturu a potřebami jednotlivého umělce, který chtěl své dílo naplnit pravým, životným a personálně zaručeným obsahem. Čím organizovanější a programovější byla ona objektivní potřeba, tím více byl skutečný tvůrce zatlačován na okraj” (Jedlička 2009: 78). 
rzeczy zaczyna być problemem, kiedy ulega pewnej automatyzacji, a samo zabranie głosu w społecznej lub politycznej dyskusji zyskuje status wydarzenia literackiego. Wobec absencji niezależnej krytyki na wychodźstwie coraz wyraźniej uwidacznia się ryzyko utylitaryzacji literatury. Konsekwencją takiego podejścia jest sytuacja, w której pisarz musi wypowiadać się jako komentator życia społecznego, zajmować stanowisko w sprawach niejednokrotnie bardzo odległych od literatury. Tekst siłą rzeczy staje się podrzędny wobec kontekstu. Michal sprzeciwiał się takiej wizji twórczości, podobnie jak panującemu w środowisku emigranckim przekonaniu o konieczności zajęcia przez pisarza określonego stanowiska: krytycznego wobec systemu, który opuścił, i pochlebnego wobec porządku, który go przyjął. Kontestując postulat zaangażowania, wypowiadania się w imieniu społeczności i jej spraw, Michal staje więc w opozycji do przedstawicieli elit emigranckich, jest dysydentem wśród dysydentów.

Rozgłos i uznanie, jakie przyniosła Michalowi publikacja kontrowersyjnego eseju, zaowocowały propozycją współpracy ze strony szwajcarskiej telewizji, która zamówiła sztukę opartą na motywach Wojny peloponeskiej Tukidydesa. Historia małej wyspy Melos, broniącej swojej suwerenności w obliczu zagrożenia ze strony Sparty i Aten, miała w założeniu stać się pochwałą szwajcarskiej neutralności i demokracji. I w tym wypadku ujawnił się Michalowski duch przekory - tekst, zatytułowany Wir, die Bürger von Melos (Michal 2001b), okazał się bowiem ponurym rewersem tej krzepiącej wizji: w podaniu autora Straszydeł Melijczycy są słabym i biernym narodem, niezdolnym do zjednoczenia się i podjęcia jakichkolwiek kroków nawet w chwili niebezpieczeństwa. Przemoc, której dopuszczają się Ateńczycy, jest w pewnym sensie naturalnym następstwem pasywności ofiar. Inaczej niż u Tukidydesa, w sztuce Michala najeźdźcy nie podejmują żadnych negocjacji, ale od razu przystępują do krwawej ofensywy. Świadomi swojej siły, stawiają ofiarom ultimatum: Melijczycy mogą uniknąć śmierci, jeśli poddadzą się kastracji.

Szwajcarscy producenci uznali, że tekst w takiej formie jest nie do przyjęcia: poprosili autora o zmianę zakończenia i złagodzenie drastycznego wydźwięku sztuki. Pisarz uciął dyskusję lakonicznym stwierdzeniem, że na takie ustępstwa nie szedł nawet wobec żądań komunistów, nie widzi więc powodu, dlaczego miałby je robić teraz (Štulcová 2005: 185-86). Wobec bezkompromisowego i nieugiętego stanowiska Michala, zuryska stacja 
zrezygnowała z produkcji, a tekst sztuki ukazał się dopiero w 1991 roku w czeskim przekładzie Violi Fischerovej. Pozostaje tyle zabawnym, ile osobliwym paradoksem - jednym z wielu w biografii autora Gipsowej damy że po latach doświadczeń w ustroju programowo ograniczającym wolność słowa, to właśnie w demokratycznej Szwajcarii twórczość Michala spotkała się z solidnym oporem ze strony cenzury.

Problemy, które towarzyszyły publikacji Najdroższych sasiadów i wystawieniu sztuki My, obywatele Melos, stały się tematem artykułu Možnost volit (Michal 2001c), który Michal wygłosił w 1977 roku na sympozjum „Letteratura e dissenso" w ramach weneckiego Biennale ${ }^{3}$. Tym, co uderza już od pierwszych linijek tekstu, jest chłodny, zobiektywizowany ton wypowiedzi. Michal pisze o sytuacji pisarza emigranta $\mathrm{z}$ dystansem, sugerującym, że problem dotyczy go w niewielkim stopniu - jakby chodziło o wydarzenia, które rozegrały się jakiś czas temu i nie mają już większego znaczenia. Pozorne niezaangażowanie podmiotu autorskiego manifestuje się także w użyciu pierwszej osoby liczby mnogiej, wskazującym na obecność jakiejś zbiorowości, w której ,ja” zatraca swoją odrębność. Napięcie pomiędzy ,ja” a „nie-ja” przenika zresztą całą twórczość emigracyjną autora Straszydel, czyniąc ją trudną w interpretacji, niemal nieczytelną. Tak jest i w tym przypadku - ,ja" mówiącego podmiotu depersonalizuje się już to w bezosobowym my, już to w modelowej i hipotetycznej postaci anonimowego pisarza, czy w końcu w groteskowym fantazmacie przerośniętego szczeniaka, będącego alegorią twórcy rozpieszczanego i jednocześnie niewolonego przez władzę lub opinię publiczną. Wydaje się, że nawet w artykule konferencyjnym Michal ujawnił potrzebę zamanifestowania umowności, a więc i hermetycznie pojmowanej „literackości” swojego - i każdego - tekstu. Problem uwikłania literatury w inne dziedziny życia społecznego (tak obcy reprezentowanej przez niego postawie), staje się środkiem ciężkości w analizie sytuacji pisarza tworzącego w warunkach reżimu:

Většina z nás začala vykonávat povolání spisovatele v systému, který svoje funkce spíše supluje, nežli vykonává, jak už vykonávat není s to. Literatura supluje publicistiku, lidovýchovu, politickou reklamu, často politiku samu. Spisovatel, chce-li vůbec publikovat,

3 Wystąpienie Michala zostało pierwotnie opublikowane w czasopiśmie „Listy” (nr 8, 1978), w niniejszym artykule cytuję z przedruku zamieszczonego w wydaniu z 2001 roku (Michal 2001c). 
musí suplovat za neschopnou, zato však všemocnou vrchnost, jež ho za to chválí či kárá, často stř́́davě, ještě častěji současně. Může existovat jen jako náchlebník, sociální př́ípad i proti své vůli, dítě par excellence: jednou jako občan, jednou jako autor (Michal 2001c: 663).

Kontrapunktem dla tej diagnozy jest cierpka wizja pisarza w pluralistycznym systemie, w którym literatura jest tylko jednym (bynajmniej nie niezbędnym) z wielu elementów działalności, funkcjonującej na zasadach wyznaczanych i regulowanych przez wolny rynek.

Ta druhá [společnost] na rozdíl od první svoje funkce zhusta reálně vykonává, a pokud supluje, pak zrrídka takzvaným krásným písemnictvím. Chcete-li, nemá na něm zájem, či rozhodně ne víc než si literatura dle mého názoru objektivně zaslouží. V každých novinách je napřed politika, potom hospodářství, pak zlomené nohy a sportovní stránka. Kulturní rubrika přichází nakonec, pak už jen vtip týdne. A jelikož vlastně k ničemu moc není, může si autor žít pod skříni a chodit na lovy, když nechce panečkovi na klín. Vykonává zhusta svoje spisování co zájmovou činnost, drobný odborný řemeslník, který pracuje pro úzký kruh zájemců (Michal 2001c: 663-664).

Obraz pisarza wyrobnika, wykonującego - jak każdy rzemieślnik w swojej specjalności - przyjęte zlecenie, za które dostaje pieniądze, staje się leitmotivem późniejszych wypowiedzi autora Straszydet na temat jego twórczości. Umniejszanie własnego znaczenia, porównywanie swojego pisarstwa do kiepsko opłacanego rzemiosła, tworzy linię wyznaczającą kierunek autokreacji Michala, aż do jego samobójczej śmierci w 1984 roku. Wydaje się, że podjęcie tego rodzaju gry było przewrotnym aktem sprzeciwu wobec nakładanych na twórcę zobowiązań. Autodeprecjacja, odmowa uczestnictwa w życiu literackim, stały się wentylem bezpieczeństwa: nie będąc pisarzem, nie podlega się ubezwłasnowolnieniu ze strony władz lub publiczności. Dla Michala-kontestatora był to swego rodzaju azyl, w którym mógł się schronić razem ze swoją wizją literatury wolnej od zaangażowania innego niż literackie. Odrzucenie roli pisarza oznaczało, jak można wywnioskować z powyższego cytatu, zdeprecjonowanie własnego znaczenia, ale jednocześnie umożliwiało emancypację woli, wydostanie się ze stanu „dziecięctwa”, to jest zupełnego podporządkowania „dorosłej” instytucjonalizacji. Koncepcja Michala przyjmuje więc formę tyleż radykalnej, co paradoksalnej tezy: wolność można uzyskać jedynie poprzez odrzucenie wolności - przy czym przez tę pierwszą należy rozumieć niezawisłość 
dzieła i procesu twórczego, przez tę drugą zaś nominalną (a zarazem pozorną) niezależność gwarantowaną przez sam status dysydenta czy emigranta. Uzyskanie tej pierwszej jest dla twórcy - według autora Straszydet - punktem odniesienia i celem, dla którego należy poświęcić tę drugą. Michal pisze o tym w zakończeniu omawianego eseju:

Kdo si nechce uhnít, ten musí začinat vždy znovu, dovnitř a navenek. A kdo se nechce dát krmit a vyplácet na zadek, nebot' prostě nechce, nežádá soucitu, leč ani obdivu jen za to, že nechce, at' už je snad autor nebo ne. Stal se z něho, alespoň v tomhletom dohledu, totiž dospělý pes (Michal 2001c: 664-665).

Program metodycznego negowania swojej roli jako twórcy z czasem urasta do rangi osobliwego rytuału, chorobliwego natręctwa, które szybko staje się drugim ,ja” autora. Negacja zaczyna mieć wymiar totalny: Michal nie publikuje, nie uczestniczy w życiu literackim i konsekwentnie wypiera się jakichkolwiek twórczych inklinacji (cf. Hvížd’ala 1981: 133). Staje się więc - niczym Oskar Měštáček z powieści Oty Filipa - „niepiszącym pisarzem" (Filip 2008), autorem, dla którego literatura jest rodzajem nieszkodliwego hobby. Jak już wspomniano, jest to forma autokreacji, rodzaj gestu czy też pozy, która z jednej strony wyraża właściwą naturze Michala przekorę, z drugiej zaś oznacza szansę na zachowanie niezależności, zwolnienie z obowiązku bycia dysydentem ,na pełny etat”. Owa świadomie przyjęta rola w sferze życia publicznego w zaskakujący sposób przekłada się także na sferę indywidualną, sferę ,ja" rozumianego jako podmiot twórczy. O ile jednak wobec innych Michal wypiera się swojego pisarstwa, o tyle wobec samego siebie odmawia go sobie.

W tym okresie bowiem (a mowa tu o ostatnich kilku latach przed samobójczą śmiercią autora) Karel Michal pracuje nad dwiema książkami, od ukończenia których w pewnym sensie sam się powstrzymuje. Żadna z nich się zresztą nie zachowała (oba rękopisy zaginęły), a informacje o ich treści i charakterze znane są tylko z relacji Violi Fischerovej i najbliższych przyjaciół pisarza. Pierwszą z nich, zatytułowaną Ach, synku, synku, zaczął pisać latem 1980 roku. Po kilku dniach wytężonej pracy, której efektem był ponaddwustustronicowy szkic, Michal przerwał nagle pisanie i więcej już do niego nie wrócił (na podstawie korespondencji autorki tekstu z Violą Fischerovą, 08.06.2009). Druga pozycja była zbiorem rozmaitych absurdalnych historii, których autor doświadczył w czasie służby wojskowej i pracy na 
najniższych szczeblach socjalistycznego państwa. Choć koncepcja powieści zrodziła się zaraz po przyjeździe do Szwajcarii, Michal zaczął myśleć o jej napisaniu dopiero na początku lat 80 . Powrót do tego pomysłu po kilkunastu latach dowodzi, że tekst powstawał z silnej wewnętrznej potrzeby, której nie osłabił nawet dystans czasowy. Działo się to jednak w okresie, w którym ,program negacji” zdominował już na dobre działalność autora; procesowi twórczemu siłą rzeczy musiały więc towarzyszyć sprzeczne odczucia. Wydaje się, że Michal chciał napisać książkę, której pisania jednocześnie sobie odmawiał. Pisarstwo (czy raczej nie-pisarstwo) Karla Michala znalazło się w położeniu, którego paradoksalny charakter najcelniej oddawałaby prawdopodobnie formuła Melville'owskiego Bartleby'ego: blokujące jakiekolwiek działanie „wolałbym nie”. Rezultatem owej autokontestacji był tekst, który można określić mianem antyautobiografii. Historie, które przytrafiały się pisarzowi, zostały rozdzielone pomiędzy fikcyjnych bohaterów, z których żaden nie był tożsamy z ,ja” podmiotu autorskiego. Ta technika przywodzi na myśl metodę Roberta Walsera - twórcy, o którym Elfriede Jelinek pisała jako o ,jednej z tych osób, które mówiąc «ja», nigdy nie mają na myśli siebie" (Jelinek 1998: 48).

Przywołanie nazwiska szwajcarskiego pisarza nie jest w tym kontekście przypadkowe. Wydaje się bowiem, że w losach tych dwóch autorów, tak odległych epoką, estetyką i charakterem, można dostrzec zaskakujące podobieństwa. Walser, który mówił o sobie jako o ,powieściopisarzu-rzemieślniku”, ,pisarskim tokarzu” (Żychliński et al. 2013: 125), będąc u szczytu sławy, nagle przestał tworzyć, po czym dobrowolnie przeniósł się do zakładu dla nerwowo chorych. Konsekwentnie wymawiał się od pisania, a kiedy opiekujący się nim Carl Seelig usiłował namówić go do powrotu do literatury, odpowiadał, że ,jest w zakładzie od tego, żeby być wariatem, a nie od tego, żeby pisać książki” (Coetzee 2000). Jako „niepiszący pisarz” autor Jakoba von Guntena zaczął tworzyć tak zwane mikrogramy - miniaturowe teksty, notowane ołówkiem na serwetkach, rachunkach czy skrawkach gazet. Utwory z ,obszaru ołówka”, jak nazywał je sam Walser (Żychliński et al. 2013: 129) to eseje, opowiadania i listy, zapisywane czcionką, której wysokość nie przekraczała dwóch milimetrów. W ten sposób powstało ponad pięćset kart tekstów, które aż do lat 70. XX wieku uchodziły za niemożliwe do odczytania (uważano zresztą, że są nie tylko nieczytelne, ale również zaszyfrowane). Powieść Zbój, odcyfrowana w 1972 roku, oraz 
krótkie utwory prozatorskie odczytane w latach 1981-2000 są materialną dokumentacją walki, którą szwajcarski outsider musiał wówczas stoczyć sam ze sobą - walki pomiędzy odmawianiem sobie pisania a odczuwaną wewnętrznie koniecznością komunikacji literackiej. Tworzenie nieczytelnych, ,niewidzialnych” tekstów umożliwiło wyjście z tej aporii i jednocześnie usytuowało Walsera na rubieżach historii literatury, poza wszelkimi prądami i tendencjami, w pewnym sensie także poza samą literaturą.

Paralele z losem Michala rysują się całkiem wyraźnie. Absolutny (bo nieznający wyjątku) charakter jego postawy jako kontestatora sprawił, że przejście z obszaru kultury oficjalnej do nieoficjalnej miało zupełnie inny rezultat niż w przypadku większości pisarzy emigrantów. Uzyskanie statusu, który dla dysydenta oznacza cel i kres transferu pomiędzy dwoma obszarami kulturowymi, dla autora Straszydet okazał się tylko stadium pośrednim w procesie realizacji właściwej mu koncepcji niezależności. W jego przypadku bowiem trakt ten wiódł nie tylko poza literaturę podlegającą systemow i, lecz także - podobnie jak u Walsera - poza literaturę p oj m ow a ną jako system. Ta peryferyjna pozycja czyni z Michala outsidera, którego dzieło nie pasuje do żadnego kanonu, wymyka się próbom systematycznego ujęcia, uszeregowania w ramach danego kontekstu historyczno- czy teoretycznoliterackiego. Określenie się poprzez nie-pisanie prowadzi bowiem do punktu, w którym wszelka kategoryzacja zostaje unieważniona. Ma to dwojakie konsekwencje: $\mathrm{z}$ jednej strony pisarz emigrant poniekąd sam skazuje się na banicję (podwójną), świadomie wykluczając się z literatury poprzez utrudnienie lub uniemożliwienie recepcji swojego dzieła, z drugiej zaś zyskuje szansę na uwolnienie własnej twórczości od balastu utylitaryzmu, a co za tym idzie, osiągnięcie rzeczywistej niezależności. Jest w tym rozstrzygnięciu oczywiście coś paradoksalnego: żeby ocalić swoje pisarstwo, trzeba w pewnym sensie z niego zrezygnować. Przypadek Karla Michala pokazuje, że podjęcie tak radykalnej decyzji jest możliwe, co więcej - kiedy stawką jest autonomia aktu twórczego, staje się koniecznością, nawet za cenę ryzyka, jakie ze sobą niesie. 


\section{Literatura}

CoetzeeJ.M.,2000, The genius of Robert Walser, ,The New York Review ofBooks”, $<$ http:// www.nybooks.com/articles/archives/2000/nov/02/the-genius-of-robertwalser/?pagination $=$ false $>, 28.06 .2013$.

Czaplińska J., 2006, Tożsamość banity. Problematyka autoidentyfikacji w młodej czeskiej prozie emigracyjnej po 1968 roku, Szczecin.

Czernikow O., 2010, Identita na rozhraní. Já a ne-já v eseji Přemilí sousedé Karla Michala, w: Česká literatura rozhrani a okraje. IV. Kongres světové literárněvědné bohemistiky Jiná česká literatura (?), red. L. Jungmannová, Praha, s. 381-390.

Filip O., 2008, Sasiedzi i ci inni, przeł. J. Stachowski, Wrocław.

Fischerová V., 2008, O straszydłach Karla Michala, przeł. D. Dobrew, w: K. Michal, Straszydla na co dzień, przeł. D. Dobrew, Wrocław, s. 145-161.

Hvížd’ala K., 1981, České rozhovory ve světě, Köln.

Jedlička J., 2009, Okraj a střed, w: idem, České typy a jiné eseje, Praha, s. 75-80.

Jelinek E., 1998, Er nicht als er (zu, mit Robert Walser), Frankfurt am Main.

Kroutvor J., 1990, Potiže s dějinami. Eseje, Praha.

Masáková M., 2001, Komentář, w: K. Michal, Soubor díla, red. i posł. M. Masáková, Praha, s. 667-685.

Michal K., 2001a, Přemili sousedé, w: idem, Soubor dila, red. i posł. M. Masáková, Praha, s. 553-562.

Michal K., 2001b, My, občané melští, w: idem, Soubor díla, red. i posł. M. Masáková, Praha, s. 601-661.

Michal K., 2001c, Možnost volit, w: idem, Soubor dila, red. i posłowie M. Masáková, Praha, s. 662-665.

Štulcová M., 2005, Osudový exil. S Violou Fischerovou hovoři Magdalena Štulcová, „Revue Prostor” nr 67-68, s. 181-190.

Walser R., 2013, Mikrogramy, przeł. M. Łukasiewicz, Ł. Musiał, A. Żychliński, Kraków. Żychliński A., Musiał Ł., Łukasiewicz M., 2013, Posłowie, w: R. Walser, Mikrogramy, przeł. M. Łukasiewicz, Ł. Musiał, A. Żychliński, Kraków, s. 125-136. 